organs are kept moist and brought immediately into pure air or oxygen again.

It is believed that these experiments upon the action of contact insecticides justify the following statements:

Contact insecticides as a rule effect the death of the insect through more than one cause.

Alkaline insecticides, such as the strong soap washes pass rather slowly through the chitinous walls of insects and dissolve the proteids and fats of the tissue cells.

Corrosive sublimate and similar substances, which in solution precipitate proteids, pass slowly through the chitinous walls of insects and precipitate the proteids of the tissue cells.

Most gases penetrate the chitinous walls of insects into the body, rapidly-much more rapidly than liquids.

Gases and liquids may enter the trachex through the spiracles and there penetrate the walls of the trachex into the body tissues of the insect more rapidly than through the outer chitin. Apparently the more feeble the surface tension of the liquid, the more readily is it able to enter the spiracles of the insect.

In the case of gasoline, kerosene, carbon disulphide and many such insecticides which are volatile, the volatile portions penetrate the body through the tracheæ and through the outer chitin, thus affecting the insect long before the liquid alone would have time to do so. Such insecticides may plug the trachex to some extent, but they appear to be effective principally through their ability to interfere, in some way, with the processes of oxidation in the tissue cells.

\title{
SOME PROPERTIES THAT MAKE LIME-SULPHUR WASH EFFECTIVE IN KILLING SCALE-INSECTS.
}

(Abstract)

By G. D. Shafen, East Lansing, Mich.

In making a study of how the lime-sulphur wash kills scale-insects, it was found that after treatment with the spray, for several hours before death results, many of the insects lie under their scale coverings in a more or less comatose condition. During this time, if the scale is removed, the insect speedily recovers the ability to respond when touched with a needle. Of course after a few hours in dry air the delicate bodied insect would shrivel and die, but fresh air seemed to be the thing that revived it when the covering was first removed.

Haywood ('07) showed that lime-sulphur sprays contain polysul- 
phides of calcium which become oxidized on exposure to air; the products of this oxidation being, at first, calcium thiosulphate and free sulphur. The thiosulphate, itself, he found to be finally oxidized to calcium sulphate. In order to determine whether this process of oxidation might deprive a scale-insect of oxygen when treated with a lime-sulphur wash, measured amounts of the spray were placed either on absorbent paper or glass-wool in containers above mercury with measured amounts of air. Then after various periods of time, the amount of oxygen in the confined air was determined. In this way, it was found that large amounts of oxygen are required to oxidize the calcium polysulphides present. For example, a piece of absorbent paper $(10 \times 12 \mathrm{~cm}$.$) saturated with lime-sulphur (Baume 20.1 { }^{\circ}$ ) used 87.5 ce. of oxygen in sixteen and one-half hours. If the paper on which the solution was placed remained moist, the polysulphides would all be oxidized in a few hours. If the paper were quickly dried, the remaining sulphides oxidized much more slowly, requiring several days. The thiosulphate of calcium oxidized more rapidly when kept moist than when dry, but in any case, it used oxygen more slowly than the sulphides.

It was found, moreover, that the bark of a dormant apple tree at $11^{\circ}$ to $12^{\circ}$ (C. was using small amounts of oxygen and giving off carbon dioxide. The space benzath a scale covering on such a tree, freshly sprayed with lime-sulphur, must therefore be losing its oxygen from three causes-namely, the oxidation of the lime-sulphur, the respiration of the bark of the tree and of the insect itself. Very few specimens of San José scale could recover after being kept 14 hours in an atmosphere of pure nitrogen.

It was found, also, that lime-sulphur is able to soften the wax around the outer edge of the scale covering of very many of the scales. The older, firmer wax did not dissolve. If the spray passed under the scale covering, its presence could be detected there by the use of corrosive sublimate which gives a black precipitate with the polysulphides of calcium. If only the thiosulphate remained its presence could be detected by silver nitrate with which a black precipitate results.

When the wax, softened by lime-sulphur around the edges of the scale, dries, it often sticks the scale covering so firmly to the surface of the plant as to seal the insect. Sometimes the pygidium was found sticking fast to the dry scale covering. In the case of Aspidiotus ficus on orange, seven days after spraying, as many as 22 dead young, 9 living young, and 4 eggs were found sealed in beneath the shield with the mother. Such confinement of course must result in the death of all the family in a few days. After three to four weeks it was found that in many cases, the oxidized salts in the wax of the scale stooled 
up forming a white crust which lifted the scale covering so that it might easily be washed or brushed from the tree, thus exposing any helpless insect, not already dead, to weather conditions.

Sulphur dioxide could not be detected coming from a surface treated with lime-sulphur wash, unless when nearly dry, the surface was exposed to temperatures high enough to rapidly vaporize the free sulphur present. It would seem therefore that under natural conditions sulphur dioxide is not formed in sufficient quantity to be of any insecticidal value.

If carbon dioxide is dissolved in lime-sulphur wash, hydrogen sulphide will be formed. This gas is poisonous to insects; but no means was found of proving its presence in effective amounts beneath scales treated with lime-sulphur.

It was not found with certainty, in any case, that lime-sulphur wash penctrated into the body of the insect, although it would kill the cells of a small part of an insect's body touched by it, while other parts of the body remained alive for a time.

The experiments therefore, seem to show that with lime-sulphur wash, it is mainly the combination of the three properties or conditions already described which makes the insecticide so efficient against scale-insects-especially against San José scale which winters in a partially grown condition.

Mr. Headlee: I have enjoyed this paper very much, and wish to thank Mr. Shafer for it. It is a type of work we ought to have more of. A few thoughts occurred to me while this paper was in process of being given, and one of them is this: Why does the author think that gasoline dissolved out parts of the fat body? Is it not possible that something else entered in and produced the same morphological result?

Mr. Shafer: Mr. President, I think the gasoline affected the "fat body," because in every case where it, alone, was tested for the right length of time, gasoline dissolved the fat body. If kerosene were used it would leave the fat body intact after two hours' treatment. This did not affect the fat body very rapidly, but after a certain number of hours, say eight or ten, I found that the "fat body" began to be dissolved, and in the case of gasoline, if the insect be left in for say twenty-four to thirty hours it will dissolve practically all the fat of the "fat body." The fat will be in solution in the gasoline, so that we can say that is the agent bringing about this result.

Gasoline and kerosene, however, kill the insect before any noticeable solution of the fat body takes place. It is the alkaline wash that can dissolve the "fat body" in one portion of the body of an insect while the other portions of the body are still alive and able to move for a time. 
Mr. Lowe: I wish also to compliment Mr. Shafer upon his work; it is very, very excellent, and right along my line. I am sorry I have not got our chemist here to dip into the chemical questions he raised. But my findings, I am sorry to say, are not entirely in accordance with his, particularly in some of the fumigants mentioned, which I found did not kill, and some substances I found killed certain insects, and had no effect upon others. There is one other point, and that is clogging spiracles. I have made many experiments along that line, with a great many substances, and have not been able yet to clog the spiracles of an insect. I have used the Cecropia caterpillar, painting the spiracles with kerosene, but have not been able to kill the insect. There is another thing, some of the insecticides, such as ordinary pyrethrum, will kill insects, but other substances equally fine, such as flour and many other substances, have no effect upon the insect when they are entirely immersed in them. I have many criticisms of the paper, but they are more in the light of friendly discussion than criticism.

Prisidint Sanderson: This paper is undoubtedly one we want to digest somewhat bafore we can discuss it intelligently. We have certainly felt the need of some work of this kind, those of us who have attempted to teach the whys and wherefores of insecticides.

We will now take up the symposium on "Present Methods of Teaching Entomology." The paper prepared by Professor Comstock will be read by Mr. Ruggles.

\section{THE PRESENT METHODS OF TEACHING ENTOMOLOGY}

By J. H. Constock, Ithaca, N. Y.

The present methods of teaching entomology followed in the United States have been developed almost entirely by men now teaching this subject. A second generation of teachers has begun its work; but the first is still on the stage. We have progressed far enough, however, to make it worth while for the teachers to compare methods, in order that each may profit by the experience of the others.

In a conference of this kind the contribution of each to the discussion will be, naturally, at first, merely a statement of the methods evolved in our several widely separated institutions. Then can follow comparisons and discussions of the various methods, which may result in the modification of each. I regret exceedingly that I cannot be present to hear the papers of my colleagues, and to take part in the discussion. But unfortunately for me, I can only send my report of progress. 